\title{
ELISA TEST FOR THE DIAGNOSIS OF CYSTICERCOSIS IN PIGS USING ANTIGENS OF Taenia solium AND Taenia crassiceps CYSTICERCI
}

\author{
Paulo Sérgio de Arruda PINTO(1), Adelaide José VAZ(2), Pedro Manuel Leal GERMANO(3) \& Paulo Mutuko NAKAMURA(4)
}

\begin{abstract}
SUMMARY
In the present study ELISA was standardized for the diagnosis of swine cysticercosis based on necropsy parameters and confirmed positive and negative control sera. Serum samples from pigs with other infections were also assayed to determine possible crossreactions. Four antigens were assayed: from Taenia crassiceps vesicular fluid (VF-Tcra) and crude larvae extract (T-Tcra), and from Taenia solium extracts of scolex (S-Ts) and of larvae (T-Ts). A checkerboard evaluation of antigen, serum and conjugate dilutions, as well as the use of Tween-20 and skim cow milk in wash and blocking solution had a marked effect on improving ELISA performance. All the antigens showed a good performance, but VF-Tcra was the best, with $96.0 \%$ and $80.0 \%$ sensitivities for cut-offs respectively at 2 sd and $3 \mathrm{sd}$, and corresponding specificities of $97.5 \%$ and $100.0 \%$. Cross-reactivity was observed only with hydatidosis and ascaridiosis. In view of the high performance observed, the ELISA test should be recommended for the diagnosis of cysticercosis in suspected swine in slaughterhouses and for the screening of cysticercosis in swine production. These results will support integrated measures of cysticercosis control throughout the chain of swine production, effectively contributing to public health.
\end{abstract}

KEYWORDS: Swine cysticercosis; Immunologic diagnosis; Standardization; ELISA, Taenia crassiceps; Antigens.

\section{INTRODUCTION}

Swine infected with Taenia solium cysticerci play a fundamental role in the transmission and maintenance of human taeniasis and cysticercosis, with the consequent need for effective services of animal health and inspection of products of animal origin. The effects of cysticerci on society are more visible in developing countries in Asia, Africa and Latin America, where these diseases should be considered a public health priority ${ }^{2,4}$.

Common procedures for the diagnosis of swine cysticercosis are in vivo examination of the tongue and post mortem anatomopathological examination. The examination of the tongue shows high specificity although its sensitivity is lower, about $70 \%$, as the anatomopathological exam which has the other disadvantage of requiring cuts in the meat, not always desirable ${ }^{6}$.

Surveys based on serological tests may contribute to a better precision of official data in inspected plants and may serve for data collection corresponding to the real slaughtering situation where there is no structure for inspection or when this structure exists but is little exploited.
The performance rates obtained for serological tests for the diagnosis of swine cysticercosis have shown wide variability, because of nonspecific or cross-reactions ${ }^{6}$.

In view of the difficulty in obtaining larval forms of $T$. solium since pigs with natural infections are reared in a clandestine manner, with the consequent impairment of the choice of adequate antigens in sufficient amounts to guarantee the homogeneity and the quality control of antigen lots, it is necessary to develop an alternative method of easy maintenance in the laboratory as a source of parasites for the preparation of adequate heterologous antigens ${ }^{15}$.

Replacement of the antigen of Taenia solium larvae by Taenia crassiceps antigen has been recommended by some authors for the diagnosis of human cysticercosis ${ }^{7,8,15}$. BIONDI et al. (1996) reported the use of a total T. crassiceps extract for the detection of serum antibodies in swine with cysticercosis, without investigating the existence of crossreactions with other disease or evaluating this test in comparison to the use of homologous antigens.

In view of the relevance of swine cysticercosis within the context of

(1) Department of Veterinary, Viçosa Federal University, 36571-000 Viçosa, MG, Brazil

(2) Faculty of Pharmaceutic Science, São Paulo University, 05508-900 São Paulo, SP, Brazil

(3) Faculty of Public Health, São Paulo University, 01246-904 São Paulo, SP, Brazil

(4) Adolfo Lutz Institute, 01246-904 São Paulo, SP, Brazil

Correspondence to: Paulo Sérgio de Arruda Pinto: Telephone: 0xx31 899 2314; Fax: 0xx31 899 2317; e-mail: pintopsa@mail.ufv.br 
public health and animal health and of the wide variation in performance of the ELISA test in the diagnosis of swine cysticercosis, the objective of the present study was to develop a proposal for the standardization of the test in question using $T$. crassiceps and T. solium antigens.

\section{MATERIALS AND METHODS}

\section{Sampling}

Sera from 25 animals maintained in a free rearing system in rural communities were used as positive control: 13 of them confirmed by anatomopathological examination and 12 from locations with recent cases of cysticercosis and showing reactivity for $T$. solium cysticerci antigens in immunoblot ${ }^{13}$.

Negative control sera were collected from 59 pigs submitted to detailed anatomopathological examination which did not present cysticerci. Fifty seven of them were from a confined rearing system and two from a free rearing system in the rural zone.

For the study of possible cross-reactions, sera were obtained from eight pigs with hydatidosis, nine pigs parasitized with Macracanthorhyncus hirudinaceus, 27 pigs parasitized with Ascaris suum, and 15 pigs with Haemophilus sp or Mycoplasma sp pneumonia. The first two groups were from a free rearing system and the last two from confined rearing.

\section{Antigens}

Taenia solium (Tso) larvae were extracted from the meat and viscera of a pig with intense natural infection, avoiding muscle tissues. After several washes in $0.15 \mathrm{M} \mathrm{NaCl}$, the calcified and degenerated cysticerci were discarded and the remaining ones were divided into two portions, one for preparing a total antigen (T-Tso) and the other for the separation of the scolex and preparation of the antigen S-Tso. T. crassiceps (Tcra) larvae were obtained as described by VAZ et al. (1997).

Antigens were obtained in a similar manner, as described. Cysts or scolexes were dehydrated by lyophilization and then pulverized in a mortar. Saline was added to the material obtained for homogenization with a Potter type blender in an ice bath. The mixture was then submitted to four ultrasound cycles of 30 seconds each at $1 \mathrm{~mA}$ and $20 \mathrm{~Hz}$, followed by centrifugation at $16,800 \mathrm{~g}$ for $30 \mathrm{~min}$ at $4{ }^{\circ} \mathrm{C}$.

To obtain the VF-Tcra antigen, fresh cysticerci were ruptured with a glass rod and centrifuged at $4,200 \mathrm{~g}$ for $30 \mathrm{~min}$ at $4{ }^{\circ} \mathrm{C}$. The supernatant obtained was treated with ultrasound and centrifuged at $16,800 \mathrm{~g}$ for 30 $\min$ at $4{ }^{\circ} \mathrm{C}$.

The supernatants obtained corresponded to the respective antigens which were stored at $-20{ }^{\circ} \mathrm{C}$ after the addition of phenylmethylsulfonyl fluoride (PMSF).

\section{Standardization of ELISA}

Flat-bottom polystyrene plates were sensitized with the antigens diluted in $0.5 \mathrm{M}$ carbonate-bicarbonate solution, $\mathrm{pH} 9.6$, for $1 \mathrm{~h}$ at room temperature and for an additional $12 \mathrm{~h}$ at $4{ }^{\circ} \mathrm{C}$. After washing with saline containing $0.05 \%$ Tween-20, non-specific reactive sites were blocked by incubation with PBS, $\mathrm{pH} 7.4$ containing skim milk (5\%), for $1 \mathrm{~h}$ at $37^{\circ} \mathrm{C}$. New washes were performed and the samples diluted in PBS-1\% skim milk were incubated for $30 \mathrm{~min}$ at $37^{\circ} \mathrm{C}$. After washing procedures, peroxidase-labeled anti-swine IgG conjugate (A-5670 Sigma Chemical Co., St. Louis, MO) was then added and the incubation and washing procedures repeated. The reaction was developed for $5 \mathrm{~min}$ with a $0.1 \%$ solution of o-phenylenediamine and $0.1 \% \mathrm{H}_{2} \mathrm{O}_{2}(\mathrm{v} / \mathrm{v})$ in $0.2 \mathrm{M}$ citratephosphate buffer and then blocked with $4 \mathrm{~N} \mathrm{H}_{2} \mathrm{SO}_{4}$. In the test, volumes of $100 \mu \mathrm{l}$ were added, except for the blocking solution which was added at $200 \mu \mathrm{l}$. The tests were performed in triplicate and absorbances (OD) read at $492 \mathrm{~nm}$.

Antigen, serum and conjugate were first checkerboard titrated in order to define the best concentrations for each of the four antigens. The selection criterion was based on the amplitude of the difference between the OD of the weakest positive serum and the OD that represented the cut-off (mean of four negative control sera $+2 \mathrm{SD})^{12}$. The performance of the four antigens was then analyzed simultaneously and other interfering factors such as time of serum incubation, conjugate and substrate, plate sensitization, and blockade.

In the last step the four antigens were assayed in the presence of all sera, i.e., positive controls (25), negative controls (59) and sera from animals with other diseases (59). Considering anatomopathological examination as the gold standard, we calculated sensitivity, specificity, positive and negative predictive values, and intragroup correlation coefficient $(\mathrm{K})^{5}$.

\section{RESULTS}

In the initial phase of standardization the results of the checkerboard titrations of the best serum and conjugate dilutions and concentration of the four antigens used indicated the tendencies of the best blocks in terms of differentiation between the weakly positive serum and the four negative sera. The best result, i.e. the highest amplitude of the difference in OD between negative and weakly positive sera (89.2\%) was obtained with the VF-Tcra $2 \mu \mathrm{g} / \mathrm{ml}$ antigen, with sera diluted 1:400 and with the conjugate diluted at 1:1,000, which were then chosen for standardization.

The other antigens yielded lower amplitude values: S-Tso $(5 \mu \mathrm{g} / \mathrm{ml}$ - serum 1:100 - conjugate 1:1,000) and T-Tcra $(10 \mu \mathrm{g} / \mathrm{ml}$ - serum 1:400 - conjugate 1:20,000), with about $25 \%$ amplitude differentiating between positive and negative. The T-Tso antigen $(2 \mu \mathrm{g} / \mathrm{ml}$ - serum 1:400 conjugate 1:20,000) showed only a $10 \%$ difference between positive and negative readings. Although these results showed better amplitude, when their OD values were either very high or very low, more adequate readings were obtained with the blocks $(5 \mu \mathrm{g} / \mathrm{ml}$ - serum 1:100 - conjugate $1: 20,000)$ and values of approximately $10 \%$ differential amplitude were obtained for the three antigens.

When the four antigens were compared simultaneously, each with its best block, the better performance of the VF-Tcra antigen in differentiating weakly positive from negative sera was confirmed (Figure 1 ), and this antigen was selected to continue standardization.

When investigating the best conditions for the test with the VF-Tcra antigen we selected periods of incubation of $30 \mathrm{~min}$ for serum and conjugate and of $5 \mathrm{~min}$ for the substrate, using serum at 1:400 dilution. 


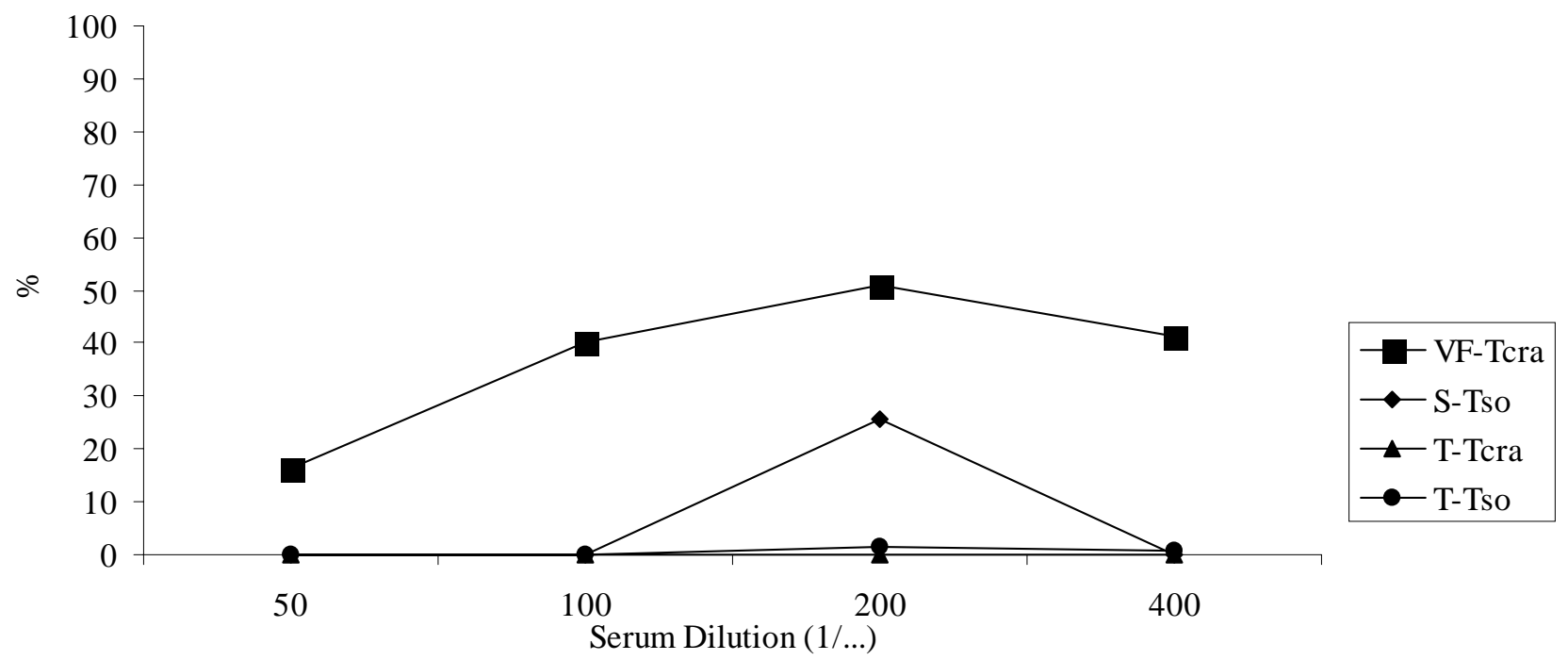

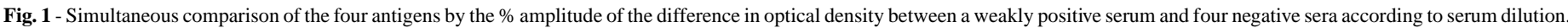

None of the periods tested for plate sensitization $\left(12 \mathrm{~h}\right.$ at $4{ }^{\circ} \mathrm{C}$ and 1 $\mathrm{h}$ at $37^{\circ} \mathrm{C}$ ) showed any particular advantage. The sensitization for $12 \mathrm{~h}$ at $4{ }^{\circ} \mathrm{C}$ was used for the subsequent tests.

The test performed in the absence of plate blockade and without Tween-20 in the washing and diluting solutions showed a high background, which did not permit the discrimination of positive and negative sera. Skim milk at $5 \%$ concentration showed a better performance in the blockade of the remaining reactive sites in the plates than bovine albumin or gelatin.

Serum samples were assayed with the four antigens using the ideal test conditions. The cut-off was calculated as the mean OD plus 2 sd or 3 sd for the negative control group and the results obtained with the two criteria are presented in Figs. 2, 3, 4 and 5 for each antigen, respectively.

Cross-reactions were observed with hydatidosis and ascaridiosis sera, but not with sera from animals with macracanthorhyncosis or pneumonia.

Table 1 shows the results of the performance of the four antigens in the presence of all sera analyzed.

The calculation of the cut-off at 2 sd always left at least one serum from the control group as nonspecifically reactive, while at 3 sd this nonspecificity only persisted for the S-Tso and T-Tcra antigens. On the other hand, as the cut-off was increased to 3 sd, the sensitivity was reduced for all four antigens. The Tcra antigens presented higher sensitivity in the detection of swine cysticercosis and with a cut-off at 2 sd the T-Tcra antigen detected all positive sera and showed high specificity (98\%). On the other hand, VF-Tcra showed $100 \%$ specificity for a cut-off at $3 \mathrm{sd}$.

\section{DISCUSSION}

The good performance of the antigens from T. crassiceps larvae in the ELISA test detected in the present study and the easy derivation and maintenance of the parasites indicate the suitability of these antigens as substitutes of $T$. solium larval antigens for the diagnosis of swine cysticercosis. Furthermore, they do not present swine proteins, which are present in lots of $T$. solium larvae, probably being responsible for the nonspecific reactions. This interference can also explain the low amplitude of the difference in OD between negative and weakly positive samples when the T-Tso antigen was used compared to S-Tso during the early phase of standardization of the ELISA test (Figure 1), showing that the scolex antigen is more specific than the total one, in agreement with NASCIMENTO \& ARAÚJO (1982).

It is also assumed that the use of $T$. crassiceps larvae may eliminate the difficulties in the localization of sources of $T$. solium parasites ${ }^{8,15}$, as well as the antigenic heterogeneity due to the different lots of $T$. solium cysticerci and laboratory extractions ${ }^{7,8}$.

The intense and ample cross-reactivity between the peptides present in the antigenic extracts of $T$. crassiceps and $T$. solium larvae, previously confirmed in human cysticercosis ${ }^{7,15}$ and in cross-immunity studies on mice ${ }^{14}$, also support the option of using these antigens in the diagnosis of swine cysticercosis.

It should also be pointed out that we detected no reports of the use of the VF-Tcra antigen for the diagnosis of swine cysticercosis and that the T-Tcra antigen previously studied ${ }^{1}$ had not been analyzed for crossreactions with other parasitoses.

The occurrence of cross-reactions with other diseases commonly occurring in pigs was observed in one of the eight animals with hydatidosis and in two of the 27 animals with ascaridiosis. These frequencies were higher than those observed with healthy animal sera. PATHAK et al. (1994) also demonstrated cross-reactions in pigs with hydatidosis.

In view of the variations in the performance of the ELISA test with 


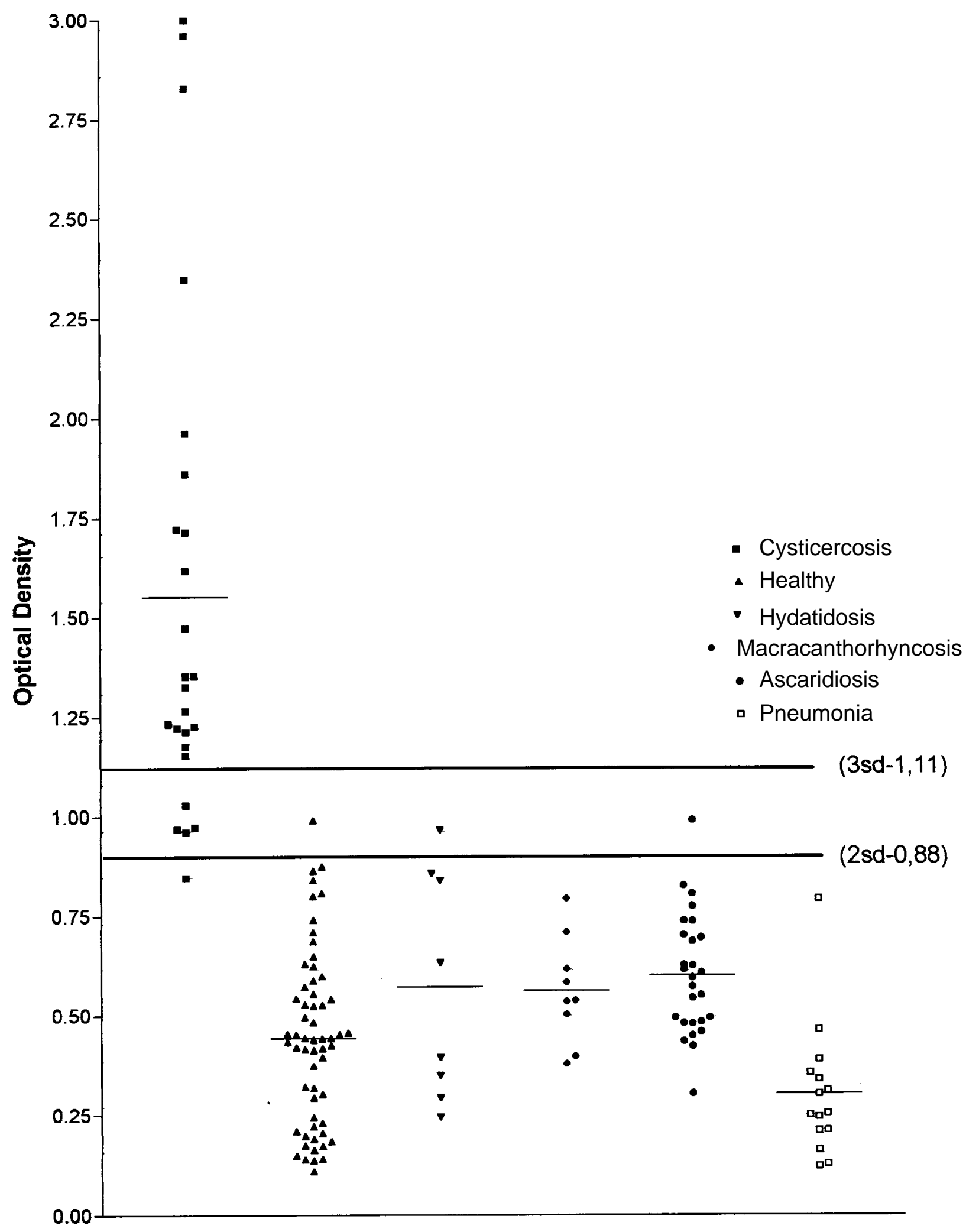

Fig. 2 - Groups of sera from healthy pigs and from pigs with cysticercosis and other diseases (ELISA with the VF-Tcra antigen). 


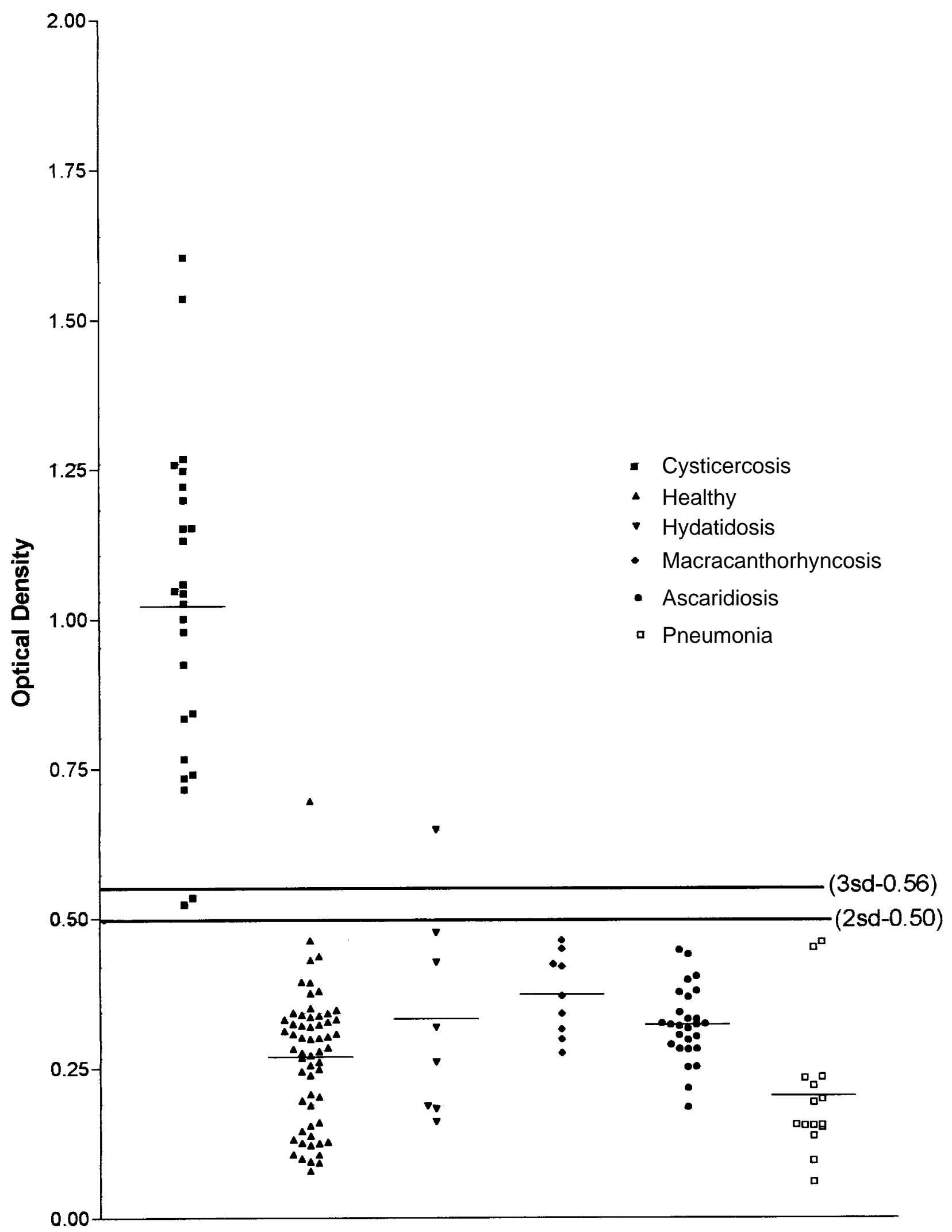

Fig. 3 - Groups of sera from healthy pigs and from pigs with cysticercosis and other diseases (ELISA with the T-Tcra antigen). 


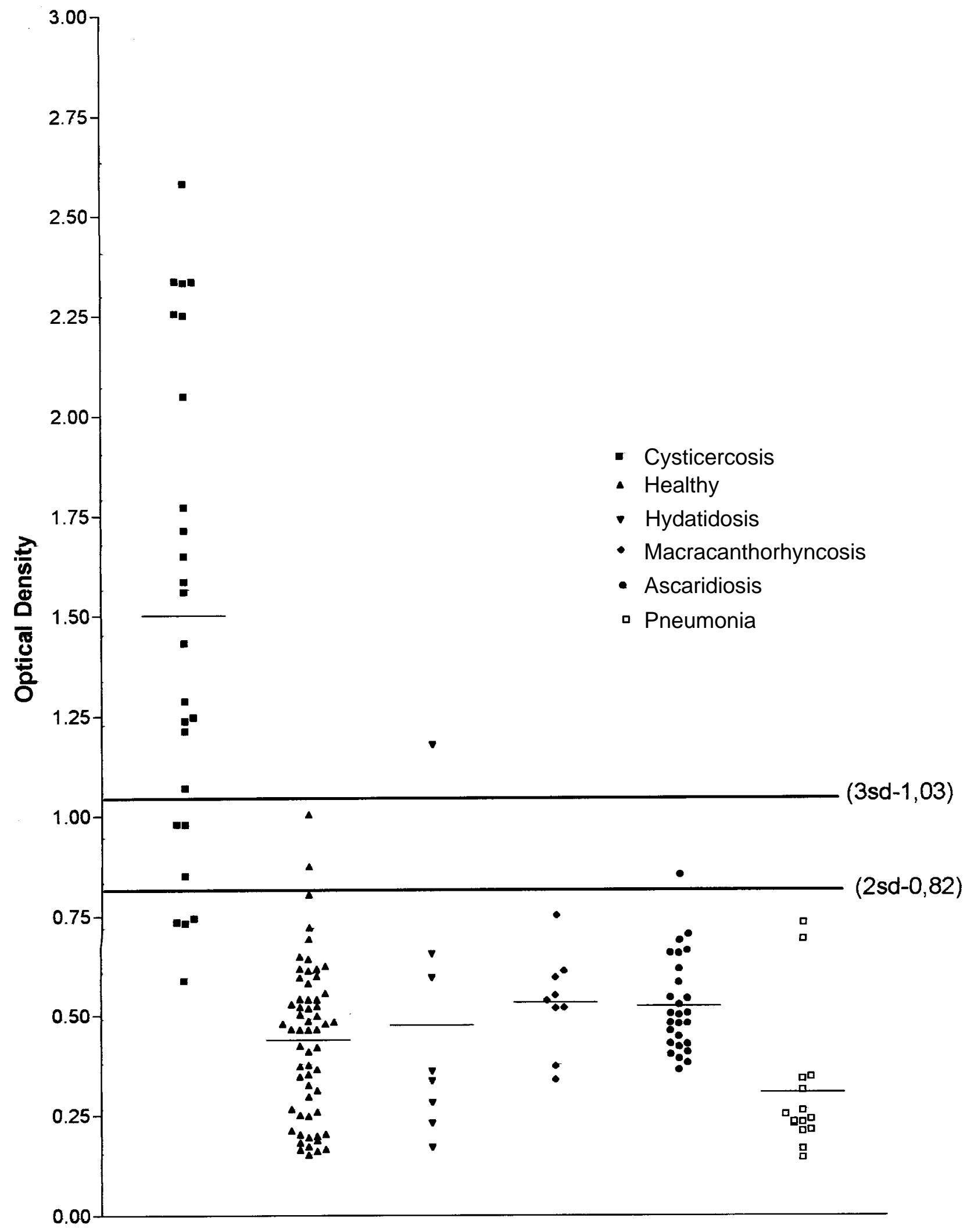

Fig. 4 - Groups of sera from healthy pigs and from pigs with cysticercosis and other diseases (ELISA with the S-Tso antigen). 


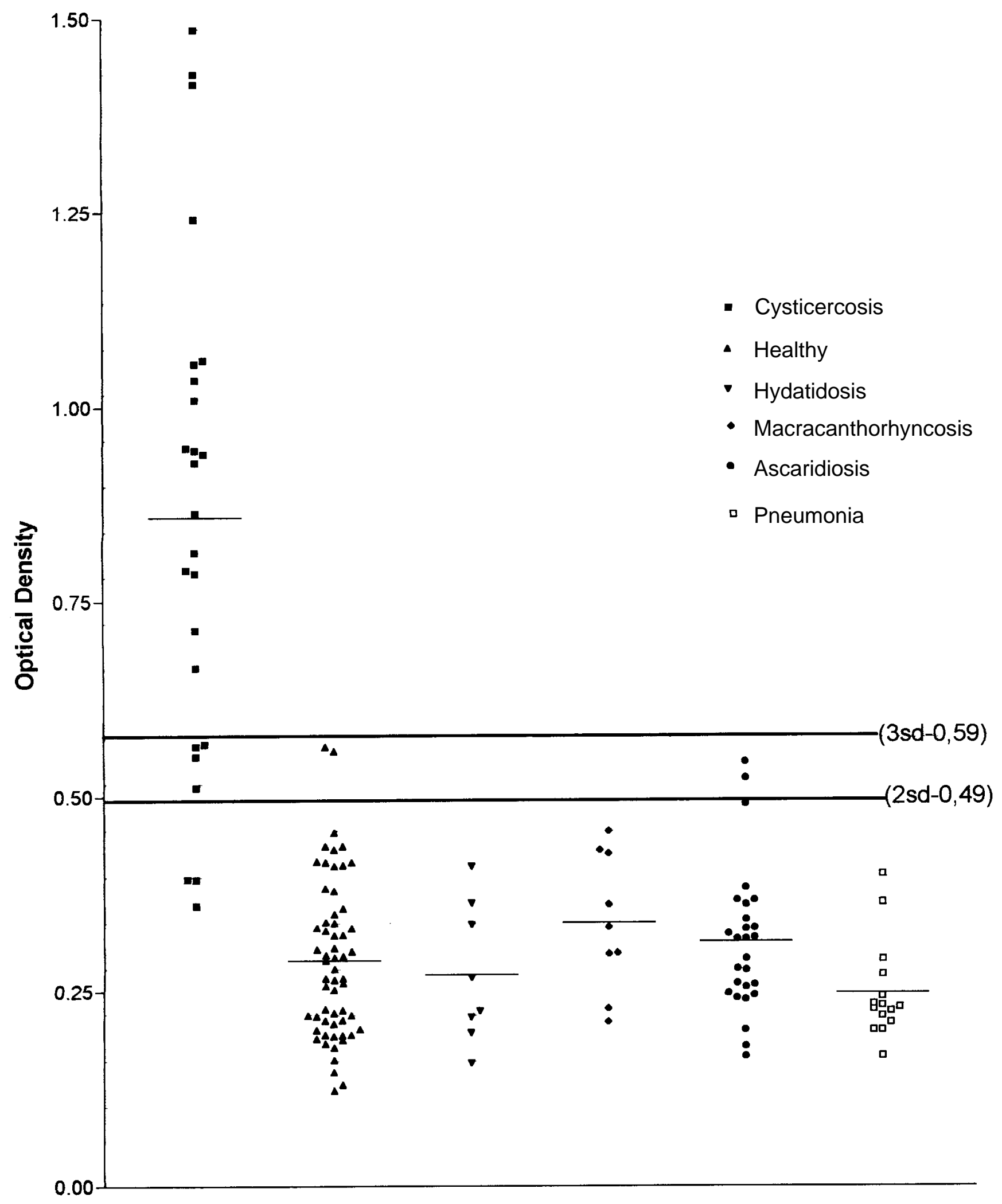

Fig. 5 - Groups of sera from healthy pigs and from pigs with cysticercosis and other diseases (ELISA with the T-Tso antigen). 


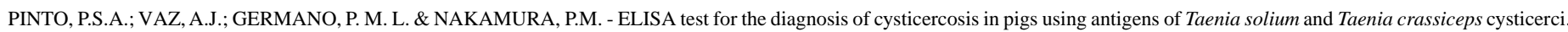
Rev. Inst. Med. trop. S. Paulo, 42(2): 71-79, 2000.

Table 1

Performance rate of the ELISA test (final phase) for the detection of antibodies in swine cysticercosis using anatomopathological examination as the gold standard

\begin{tabular}{lcccccccc}
\hline & \multicolumn{1}{c}{ Antigen/cut-off (SD) } \\
\cline { 2 - 9 } \multicolumn{1}{c}{ Rates } & \multicolumn{2}{c}{ VF-Tcra } & \multicolumn{2}{c}{ T-Tcra } & \multicolumn{2}{c}{ S-Tso } & \multicolumn{3}{c}{ T-Tso } \\
& 2 SD & 3 SD & 2 SD & 3 SD & 2 SD & 3 SD & 2 SD & 3 SD \\
\hline Sensitivity (\%) & 96.0 & 80.0 & 100.0 & 92.0 & 84.0 & 72.0 & 88.0 & 72.0 \\
Specificity (\%) & 97.5 & 100.0 & 98.0 & 98.0 & 96.5 & 99.0 & 96.5 & 100.0 \\
Predictive value + (\%) & 89.0 & 100.0 & 92.5 & 92.0 & 84.5 & 95.0 & 84.5 & 100.0 \\
Predictive value - (\%) & 96.5 & 96.0 & 98.0 & 96.5 & 94.0 & 94.0 & 94.0 & 93.5 \\
Coefficient K intragroup correlation & 0.90 & 0.85 & 0.83 & 0.91 & 0.97 & 0.90 & 0.83 & 0.81 \\
\hline
\end{tabular}

varying quantities of reagents, especially the antigen, serum and conjugate, the resource of checkerboard titration has become an absolute requirement in studies on the standardization of ELISA, as recommended by MONTENEGRO et al. (1994). The optimal concentrations of the antigens used ranged from $2 \mu \mathrm{g} / \mathrm{ml}$ (VF) to $5 \mu \mathrm{g} / \mathrm{ml}$, lower values than those reported by others ${ }^{1,3,11}$, which ranged from 10 to $11.5 \mu \mathrm{g} / \mathrm{ml}$.

The optimal serum dilutions also varied with antigen type, ranging from 1:400 (VF) to 1:100, disagreeing with the values reported by CHENG \& KO (1992) of 1:1,000 and by BIONDI et al. (1996) of 1:800, but in agreement with those reported by PATHAK et al. (1994), of 1:100. The optimal dilutions for the IgG peroxidase conjugate differed according to the antigen: 1:1,000 for VF-Tcra and 1:20,000 for the remaining ones. Each conjugate lot should be titrated under normal testing conditions.

Comparison of $5 \%$ skim milk, $1 \%$ bovine albumin and $1 \%$ gelatin as blocking solutions showed a considerable advantage for the milk, contributing to a better identification of specific against nonspecifiic reactions, in agreement with VENKATESAN \& WAKELIN (1993).

The presence of Tween-20 in serum, conjugate and blocking solutions was decisive in the widening of the differences between the OD of positive and negative sera, confirming its effect on the minimization of nonspecific reactions, together with 5\% skim milk, as pointed out by PERALTA \& FRIAS (1987) and VENKATESAN \& WAKELIN (1993).

With respect to incubation, there was no sharp difference among the antigens analyzed, with the times being fixed at 5 minutes for the substrate, 30 minutes for serum and conjugate and 12 hours at $4{ }^{\circ} \mathrm{C}$ for antigen, with the major objective of obtaining lower OD for the negative controls and for serum samples of other diseases.

The sensitivity and specificity rates for the four antigens tested were high. But the two Tcra antigens showed higher sensitivity than the two Tso antigens (Table 1). T-Tcra antigen showed a better performance, although VF-Tcra antigen showed higher specificity (100\%) and positive predictive values for 3 sd cut-off .

The standardization of the ELISA test with the use of control sera and optimal reagent concentrations, as well as the modifications in the analytical procedures of the technique traditionally employed for the diagnosis of human cysticercosis adopted in the present study seem to have increased the efficiency of this test for the diagnosis of swine cysticercosis compared to some less favorable rates obtained by others. Using the Tso antigen, other investigators have reported slightly lower rates. GONZALES et al. (1990) and PATHAK et al. (1994) observed sensitivity rates of $79.8 \%$ and $70 \%$ and specificity rates of $76.2 \%$ and $93.4 \%$, respectively.

Using T. crassiceps larvae as an antigen in the ELISA test, BIONDI et al. (1996) observed $100 \%$ sensitivity and specificity with three standard deviations as a cut-off point. The authors did not assay serum samples from swines with other parasites, which can explain such excellent rates.

The decision about the use of 2 sd or 3 sd as a cut-off criterion will depend on the purpose of the test, $3 \mathrm{sd}$ is more appropriate for diagnostic purposes and 2 sd for screening. The VF-Tcra antigen assures better results in the definitive diagnosis and the T-Tcra antigens provides better results in the screening of infected animals.

The results obtained here indicate that the ELISA test can be applied to the diagnosis of swine cysticercosis, especially in screening situations. The application of this test in epidemiological studies in Brazil may permit the identification of areas at risk to which priority should be given in terms of sanitary control actions.

\section{RESUMO}

\section{Teste ELISA para diagnóstico da cisticercose suína usando antígenos de larvas de Taenia solium e Taenia crassiceps}

Foi padronizado o teste ELISA para o diagnóstico da cisticercose suína. Após confirmação por exame post-mortem, os soros dos respectivos animais foram empregados como controles positivos e negativos. Soros de suínos portadores de infecções heterólogas foram ensaiados para determinação de reações cruzadas. Os quatro antígenos testados na fase de padronização foram líquido vesicular (VF) e extrato total (T) de larvas de Taenia crassiceps (Tcra) e de extrato de escólex (S) e de cisticercos (T) de Taenia solium (Tso). A titulação em bloco das ótimas concentrações de antígenos e diluições de soros e de conjugado, bem como o emprego 
de Tween-20 e de leite desnatado nas soluções bloqueadora e de lavagem exerceram nítida influência no desempenho do teste ELISA. Todos os antígenos revelaram bom desempenho na diferenciação entre soros positivos e negativos para cisticercose. $\mathrm{O}$ antígeno VF-Tcra apresentou as mais altas taxas de desempenho, seguido do T-Tcra. As taxas de desempenho para o antígeno VF-Tcra foram, respectivamente, para pontos de corte com 2 sd e 3 sd, de $96,0 \%$ e $80,0 \%$ para sensibilidade e de $97,5 \%$ e $100,0 \%$ para especificidade. Foi detectada reação cruzada com soros de hidatidose e de ascaridiose. Considerando o bom desempenho observado, o teste padronizado pode ser recomendado em matadouros no diagnóstico de animais suspeitos e no levantamento da ocorrência da doença nos segmentos de criação, sobretudo nos clandestinos, dando suporte às medidas de controle da cisticercose, integradas em toda a cadeia de produção da carne suína, exercendo efetiva contribuição à Saúde Pública.

\section{ACKNOWLEDGEMENTS}

We thank M.Sci. Ednéia C. Bueno for assistance in figure legends.

\section{FINANCIAL SUPPORT}

This research was supported by FAPESP (Fundação de Amparo à Pesquisa do Estado de São Paulo, Grant 1996-02235-6).

\section{COMMUNICATION}

An extract of this research was recently accepted as a short communication in the Veterinary Parasitology journal.

\section{REFERENCES}

1. BIONDI, G.F.; MUCCIOLO, R.G.; NUNES, C.M. \& RICHTZENHAIN, L.J. Immunodiagnosis of swine cysticercosis by indirect ELISA employing a heterologous antigen from Taenia crassiceps metacestode. Vet. Parasit., 64: 261-266, 1996.

2. CARRADA-BRAVO, T. - Teniasis-cisticercosis como problema de salud pública. Bol. méd. Hosp. infant. (Méx.), 44: 427-434, 1987.

3. CHENG, R.W.K. \& KO, R.C. - Purification of larval Taenia solium antigens by gel filtration. Vet. Parasit., 43: 65-73, 1992.
4. FLISSER, A.; PLANOCARTE, A. \& CORREA, D. - Diagnóstico, tratamiento y mecanismos de evasión inmune de la cisticercosis por larvas de Taenia solium en seres humanos y cerdos. Rev. Asoc. guatemalt. Parasit. Med. trop., 6: 43-54, 1991.

5. FLETCHER, R.H. - Epidemiologia clínica. 2.ed. Porto Alegre, Artes Médicas, 1991.

6. GONZALEZ, A.E.; VITALIANO, C.; GILMAN, R.H. et al. - Prevalence and comparison of serologic assays, necropsy, and tongue examination for the diagnosis of porcine cysticercosis in Peru. Amer. J. trop. Med. Hyg., 43: 194-199, 1990.

7. LARRALDE, C.; SOTELO, J.; MONTOYA, R.M. et al. - Immunodiagnosis of human cysticercosis in cerebrospinal fluid. Antigens from murine Taenia crassiceps cysticerci effectively substitute those from porcine Taenia solium. Arch. Path. Lab. Med., 114: $926-928,1990$

8. McMANUS, D.P.; BOWLES, G.L.; LEGGATT, G. \& GARCIA-ZEPEDA, E. - Some recent advances in the molecular characterization of Echinococcus and Taenia solium. Southeast Asian J. trop. Med. publ. HIth, 22: 256-261, 1991.

9. MONTENEGRO, T.; GILMAN, R.H.; CASTILLO, R. et al. - The diagnostic importance of species specific and cross-reactive components of Taenia solium, Equinococcus granulosus, and Hymenolepis nana. Rev. Inst. Med. trop. S. Paulo, 36: 327-334, 1994

10. NASCIMENTO, E. \& ARAUJO, F.G. - Estudos imunoquímicos em extratos aquosos de larva e adultos de Taenia solium. I. Imunogenicidade e composição antigênica. Rev. Inst. Med. trop. S. Paulo, 24: 353-358, 1982.

11. PATHAK, K.M.L.; ALLAN, J.C.; ERSFELD, K. \& CRAIG, P.S. - A Western blot and ELISA assay for the diagnosis of Taenia solium infection in pigs. Vet. Parasit., 53 209-217, 1994.

12. PERALTA, E.L. \& FRIAS, M.T. - Manual sobre la tecnica inmunoenzimática ELISA Havana, ENPES, 1987.

13. PINTO, P.S.A. - Diagnóstico imunológico da cisticercose suína como contribuição à inspeção de carnes. São Paulo, 1998. (Tese de Doutorado - Faculdade de Saúde Pública da Universidade de São Paulo).

14. SCIUTTO, E.; FRAGOSO, G.; TRUEBA, L. et al. - Cysticercosis vaccine: cross protecting immunity with $T$. solium antigens against experimental murine $T$. crassiceps cysticercosis. Paras. Immunol., 12: 687-696, 1990.

15. VAZ, A.J.; NUNES, C.M.; PIAZZA, R.M.F. et al. - Immunoblot with cerebrospinal fluid from patients with neurocysticercosis using antigen from cysticerci of Taenia solium and Taenia crassiceps. Amer. J. trop. Med. Hyg., 57: 354-357, 1997.

16. VENKATESAN, P. \& WAKELIN, D. - ELISAs for parasitologists: or lies, dammed lies and ELISAs. Parasit. today, 9: 228-232, 1993.

Received: 18 October 1999

Accepted: 22 December 1999 